\title{
POLA PENATAAN RUANG PANTI JOMPO BERDASARKAN AKTIVITAS DAN PERILAKU PENGHUNINYA
}

\author{
(Studi Kasus: Panti Jompo Wisma Mulia Jakarta, Senjarawi Bogor dan \\ Muara Kasih Bogor)
}

\author{
Evian Devi \\ Magister Arsitektur, Program Pascasarjana, Universitas Katolik Parahyangan, Bandung, Indonesia \\ Email: vian.tjen@gmail.com
}

\begin{abstract}
Abstrak
Kenyamanan fisik pada suatu bangunan dapat memberi pengaruh bagi psikologis penghuninya. Dalam perancangan Panti Jompo, dimana penghuninya adalah lansia, tentunya berbeda kenyamanan fisiknya dengan manusia yang masih muda. Oleh karena itu diperlukan pemahaman tentang karakteristik lansia. Penyakit degeneratif pada lansia menyebabkan perlunya perhatian khusus dari segi arsitektur terutama dalam hal keselamatan dan kenyamanan. Namun sebagian besar Panti Jompo saat ini belum terlalu memperhatikan hal tersebut sehingga masih banyak ditemukannya lansia yang mengalami kecelakaan saat beraktivitas serta depresi di Panti Jompo. Penelitian ini bertujuan untuk mengetahui hubungan yang terjalin antara aspek kenyamanan dan keselamatan bagi lansia dalam perancangan Panti Jompo sehingga lansia merasa nyaman dan senang tinggal di hunian tempat tinggalnya. Langkah-langkah metode penelitian ini adalah sebagai berikut: pertama, memahami kriteria lansia secara teoritis melalui literatur terkait dan hasil observasi mengenai lansia serta literatur terkait lainnya yang berhubungan dengan keselamatan dan kenyamanan. Kedua, studi literatur tersebut digunakan untuk menganalisis kasus studi yaitu Panti Jompo Wisma Mulia (Jakarta), Panti Jompo Senjarawi (Bandung), dan Panti Jompo Muara Kasih (Bogor). Hasil dari analisa terhadap ketiga kasus studi berdasarkan studi literatur, menghasilkan sebuah kriteria perancangan arsitektur untuk hunian lansia. Hasil penelitian menyimpulkan bahwa dalam perancangan hunian yang nyaman dan aman terhadap resiko kecelakaan yang mungkin terjadi pada lansia, diperlukan sirkulasi yang dapat dilalui dua buah kursi roda secara bersamaan dan bebas hambatan, disediakan handrail pada jalur sirkulasi, disediakan ramp pada perbedaan ketinggian lantai, dan penggunaan warna yang kontras namun dominan ringan dan hangat. Pertimbangan lain yaitu fasilitas yang menunjang psikologis lansia misalnya tersedianya ruang nostalgia, ruang bermain anak dan fasilitas lain yang menarik keluarga untuk lebih sering berkunjung.
\end{abstract}

Kata kunci: Lansia, keselamatan, kenyaman, panti jompo.

\begin{abstract}
Title: Living Arrangement Pattern Nursing Home Occupants Based Activities and Behavior

Physical comfort in a building can give an effect to the psychological inhabitans. In the design of nursing homes, where the residents are elderly, certainly they have a different physical comfort with a younger people. The degenerative disease on elderly cause the need for special attention in architecture, especially on safety and comfort. Currently the nursing homes, mostly do not noticed it well, so still discovered lots of the elderlies got an accident and depressed in a nursing home. This research purpose to know the relationship between the aspects of both comfort and safety for elderly in nursing home that can make the elderly feel comfortable and happy living in their residence. The methods of this research is as follows: first, understand the criteria of elderly in related literatures and observations regarding to the elderly and other related literatures that subscribe with safety and
\end{abstract}


comfort. Second, the literatures study were used to analyze the case study such as Nursing Home Wisma Mulia (Jakarta), Nursing Home Senjarawi (Bandung), and Nursing Home Muara Kasih (Bogor). The results of analysis from the case studies based on the literature, produce an architectural design criteria for the review occupancy elderly. The results of this research concluded that the design of the comfortable and safe against risk of any accident that may occur to the elderly, provided a circulation which can be passes by two wheelchairs at once and freeway, provided handrail in the circulation, provided ramp in any difference level of floor, and using a contrast color but dominant in light and warm color. The other considerations are the availability nostalgic room, playroom for children and the other facility that make the frequency of their families, visiting more often.

Keywords: Elderly, safety, comfort, nursing homes.

\section{Pendahuluan}

Meningkatnya rasio pertumbuhan penduduk usia lanjut yang berbanding terbalik dengan pertumbuhan penduduk usia produktif di dunia terutama di negara-negara berkembang seperti di Indonesia, menyebabkan bertambahnya angka ketergantungan lansia (Buletin Lansia, 2013). Namun, perubahan sosiokultural masyarakat Indonesia berdampak pada pola pengasuhan lanjut usia dalam keluarga yang tadinya memegang pola keluarga besar 'extended family', mengarah kepada pola keluarga inti atau 'nuclear family' (Kepmensos RI, 2007). Oleh karena itu Panti Jompo menjadi salah satu solusi untuk menitipkan orang tua yang telah lanjut usia untuk dirawat dan bersosialisasi dengan sesama teman sebayanya, bahkan ada yang merupakan keinginan sendiri dengan alasan tidak ingin merepotkan keluarga atau kerabatnya dan ingin menghabiskan masa tuanya dengan tenang.

Nama Panti Jompo sendiri pada umumnya telah negatif di mata masyarakat Indonesia. Pandangan negatif ini ditambah dengan kondisi Panti Jompo saat ini masih banyak yang berdiri seadanya tanpa terlalu memperhatikan kenyamanan serta keselamatan bagi penghuninya. Sedangkan lansia cenderung mengalami penurunan fisik dan peningkatan emosional sehingga dari segi arsitektur tentunya berbeda dengan manusia saat masih muda. Menurut Undang-Undang Republik Indonesia Nomor 13 Tahun 1998 tentang Kesejahteraan Lanjut Usia bahwa upaya untuk meningkatkan kesejahteraan bagi lanjut usia selama ini masih terbatas pada upaya pemberian sebagaimana dimaksud dalam Undangundang Nomor 4 Tahun 1965 tentang Pemberian Bantuan Penghidupan Orang Jompo, yang pada saat ini dirasakan sudah tidak memadai apabila dibandingkan dengan perkembangan permasalahan lanjut usia, sehingga mereka yang memiliki pengalaman, keahlian, dan kearifan perlu diberi kesempatan berperan dalam pembangunan.

Berdasarkan fenomena-fenomena tersebut, terdapat permasalahan pada Panti Jompo yang membuat lansia merasa kurang nyaman tinggal di Panti Jompo. Oleh karena itu, dikaji beberapa objek studi untuk mendapatkan kriteria perancangan terhadap Panti Jompo. Objek studi merupakan Panti Jompo milik swasta karena biasanya penghuni Panti Jompo ini adalah lansia yang berasal dari rumah, dan tentunya sedikit 
berbeda kebutuhannya dengan lansia terlantar (biasanya dibiayai oleh Panti Jompo milik pemerintah). Objek studi juga merupakan Panti Jompo milik swasta yang cukup dikenal oleh masyarakat setempat dan sering menjadi tujuan untuk menitipkan orang tua yang telah lansia serta menjadi panutan bagi Panti Jompo yang lain sehingga sedikit banyak telah mempertimbangkan kebutuhan lansia. Panti Jompo tersebut antara lain adalah Panti Jompo Wisma Mulia (Jakarta), Panti Jompo Senjarawi (Bandung), dan Panti Jompo Muara Kasih (Bogor).

Lingkungan manusia baik yang alami maupun yang binaan memiliki pengaruh besar terhadap perasaan, perilaku, masalah-masalah kesehatan secara umum, dan produktivitas. Manusia merespon tempat tinggal dan tempat bekerjanya secara sadar maupun tidak sadar. Ketika rasa nyaman seseorang terpenuhi biasanya akan merespon secara positif pada lingkungannya, orang lebih menerima ruang dan isinya jika memberikan kenyamanan (Halim,1999). Dapat disimpulkan bahwa lingkungan baik yang alami maupun binaan sedikit banyak membawa pengaruh bagi manusia. Lingkungan yang nyaman akan memberikan dampak yang positif pula bagi psikologis penghuninya. Oleh karena itu, dalam perancangan arsitektur dibutuhkan pemahaman terhadap karakteristik penghuninya sehingga dihasilkan lingkungan binaan (arsitektur) yang sesuai dengan penggunanya. Selain itu juga dapat memberikan dampak yang positif dan menciptakan perilaku yang diinginkan. Demikian halnya dengan Panti Jompo, dengan memahami karakteristik dari lansia, diharapkan dapat menciptakan bangunan hunian yang sesuai untuk lansia.
Menjadi tua merupakan suatu proses alamiah yang terjadi pada setiap orang. Memasuki usia lanjut ditandai dengan kemunduran secara fisik maupun psikis. Dalam proses penuaan ada beberapa aspek yang mempengaruhi. Aspek-aspek penunjang proses penuaan adalah sebagai berikut:

1. Aspek Biologis:

Secara umum kondisi fisik seseorang yang sudah memasuki masa lansia mengalami penurunan secara berlipat ganda termasuk penurunan pada pancaindera (Kartinah \& Sudaryanto, 2008). Penurunan fungsi indera tersebut menurut Canter (dalam Sabrina, 2008) adalah:

a. Penurunan kemampuan visual.

b. Penurunan kemampuan pendengaran.

c. Penurunan kemampuan menyadari perubahan suhu, rasa, dan bau.

d. Penurunan kemampuan bergerak.

e. Penurunan memori.

2. Aspek Psikologis:

Perubahan yang terjadi mempengaruhi psikologis sehingga terjadi peningkatan kesensivitas emosional (Kartinah \& Sudaryanto, 2008).

3. Aspek Sosial:

a. Respon negatif mempengaruhi sikap sosial lansia sehingga cenderung mencari teman komunikasi yang sebaya.

b. Cenderung berinteraksi secara berkelompok.

Ditinjau dari penurunan yang terjadi pada lansia tersebut, hal yang penting dalam merancang hunian untuk lansia adalah kenyamanan dan keselamatan bagi lansia yang ditinjau dari segi 
arsitektur. Ada beberapa kenyamanan menurut SNI dalam bidang arsitektur yaitu kenyamanan gerak dan hubungan antarruang (statis), kenyamanan pandangan (visual), kenyamanan thermal, dan kenyamanan audial. Sedangkan Panti Jompo yang saat ini masih memiliki permasalahan misalnya material yang digunakan masih tergolong licin, sirkulasi kurang sesuai dengan ruang gerak lansia sehingga masih sering terjadi kasus kecelakaan kecil yang dialami lansia saat beraktivtias, serta tidak jarang terjadi depresi pada lansia di Panti Jompo. Tujuan dari penelitian ini adalah mengetahui hubungan yang terjalin antara aspek kenyamanan dan keselamatan bagi lansia dalam perancangan Panti Jompo sehingga dapat mendukung lansia beraktivitas secara mandiri serta merasa senang tinggal di hunian tempat tinggalnya. Mandiri di sini dalam arti kesempatan yang diberikan untuk melakukan aktivitasnya sendiri tanpa atau sedikit bantuan dari tenaga kerja Panti Jompo. Manfaat dari penelitian ini adalah masukan dan pedoman dalam merancang hunian untuk lansia. Pedoman ini dapat menjadi kriteria dan masukan untuk membangun bangunan khusus untuk lansia baik bagi pihak swasta maupun pemerintah.

\section{Material dan Metode}

Studi kasus yang dipilih merupakan Panti Jompo dari tiga kota yang berbeda sebagai perbandingan. Panti Jompo yang dipilih adalah Panti Jompo milik swasta yang cukup dikenal dan sering menjadi pilihan untuk lansia dititipkan. Masingmasing kasus studi tersebut adalah Panti
Jompo Wisma Mulia (Jakarta), Panti Jompo Senjarawi (Bandung), dan Panti Jompo Muara Kasih (Bogor). Berikut data umum kasus studi yang digunakan:

1. Kasus studi yang pertama merupakan Panti Jompo yang terletak di Jakarta Barat tepatnya di Grogol, yaitu di Jalan Hadiah No. 14-16, Kelurahan Jelambar, Kecamatan Grogol Petamburan, Jakarta Barat. Panti ini bertingkat 2 lantai dan dulunya merupakan Panti Werdha khusus wanita yang kemudian berkembang menjadi Panti Jompo campuran. Panti Jompo ini didirikan pada tahun 1961 oleh Yayasan Bina Daya Wanita dibawah binaan KOWANI (Kongres Wanita Indonesia) dengan ketua Yayasan Bina Daya Wanita.

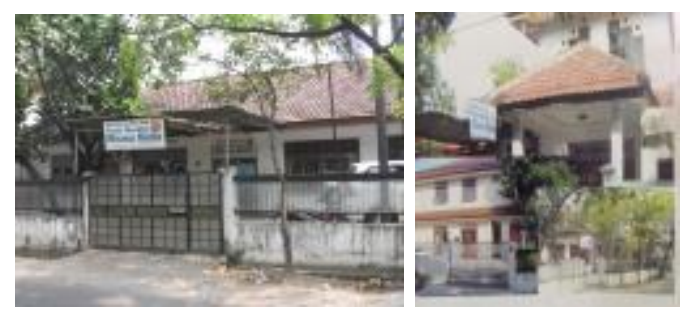

Gambar 1. Panti jompo wisma mulia Jakarta Sumber: Dokumentasi Penulis, 2016

2. Kasus studi yang kedua merupakan Panti Jompo yang terletak di Bandung tepatnya di Jalan Jeruk No. 7. Panti berjumlah satu lantai dan panti ini dulunya merupakan tempat penampungan atau penitipan anakanak keturunan Belanda kemudian pada tahun 1949 beralih fungsi menjadi Panti Jompo. Panti Jompo ini berada dalam cabang pelayanan Gereja Bala Keselamatan di Indonesia. 

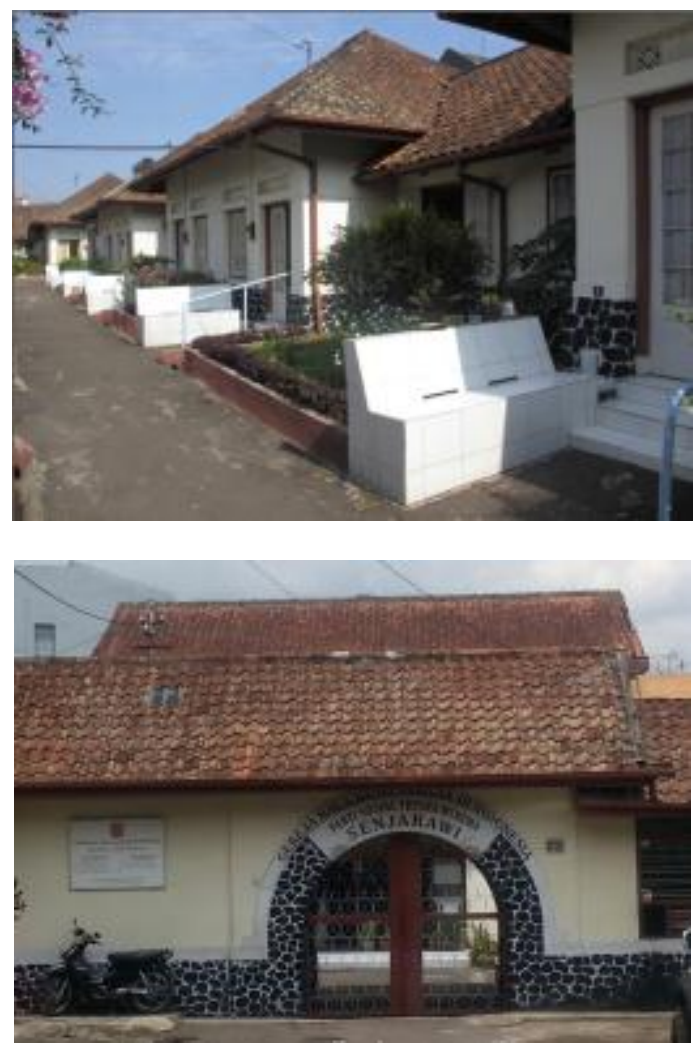

Gambar 2. Panti jompo senjarawi Bandung

Sumber: Dokumentasi Penulis, 2016

3. Kasus studi yang ketiga merupakan Panti Jompo yang terletak di Bogor tepatnya di, yaitu di Jalan Raya Kemang, Perumahan Billabong Lake View, Blok E2 No. 5-6, Parung, Bogor. Panti Jompo ini didirikan pada tahun 1992 oleh Yayasan Perniagaan Satu.
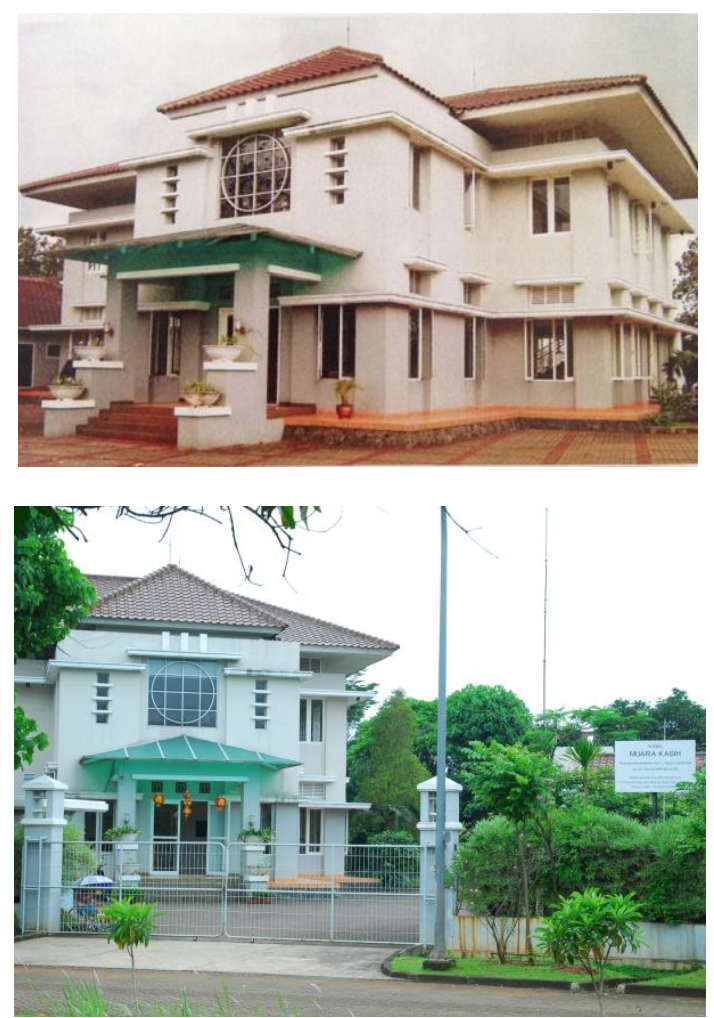

Gambar 3. Panti jompo muara kasih Bogor Sumber: Dokumentasi Penulis, 2016

\section{Langkah dan analisis}

Langkah analisis dalam penelitian ini adalah pertama, menemukan literatur terkait dari karakteristik lansia, kenyamanan dan keselamatan bangunan pada umumnya hingga kaitan kenyamanan dan keselamatan lansia pada arsitektur terhadap hunian tempat tinggalnya. Kedua, menemukan aspekaspek yang berhubungan dengan kenyamanan dan keselamatan untuk lansia tersebut untuk dianalisis pada studi kasus. Adapun aspek-aspek yang perlu diperhatikan adalah sebagai berikut: 
Tabel 1. Kriteria perancangan yang berhubungan dengan kenyamanan dan keselamatan lansia

\begin{tabular}{|c|c|c|c|}
\hline \multicolumn{2}{|c|}{ Karakteristik Lansia } & $\begin{array}{c}\text { Kriteria Keselamatan dan Kenyamanan } \\
\text { Bangunan untuk Lansia }\end{array}$ & \multirow{2}{*}{$\begin{array}{c}\text { Aspek } \\
\text { Kenyamanan }\end{array}$} \\
\hline \multirow[t]{21}{*}{ Biologis } & \multirow[t]{2}{*}{ Mudah merasa lelah } & $\begin{array}{l}\text { - Jarak antar ruang yang digunakan sehari-hari } \\
\text { saling berdekatan atau tidak lebih dari radius } 40 \\
\text { m. }\end{array}$ & \\
\hline & & $\begin{array}{l}\text { - Sirkulasi yang panjang sebaiknya disediakan } \\
\text { tempat duduk untuk istirahat. }\end{array}$ & Kenyamanan \\
\hline & \multirow[t]{5}{*}{$\begin{array}{l}\text { Menggunakan alat bantu } \\
\text { untuk berjalan }\end{array}$} & $\begin{array}{l}\text { - Sirkulasi minimal dapat dilalui dua buah kursi } \\
\text { roda secara bersamaan }\end{array}$ & Kenyamanan \\
\hline & & $\begin{array}{l}\text { - Ruang memiliki sirkulasi minimal 50\% dari luas } \\
\text { ruang. }\end{array}$ & Kenyamanan \\
\hline & & $\begin{array}{l}\text { - Sudut luar pada sirkulasi tidak tajam atau } \\
\text { lengkung. }\end{array}$ & Kenyamanan \\
\hline & & - Lantai relatif datar dan bebas hambatan. & Keselamatan \\
\hline & & $\begin{array}{l}\text { - Menggunakan ramp pada setiap perbedaan } \\
\text { lantai dan landai. }\end{array}$ & Keselamatan \\
\hline & \multirow[t]{4}{*}{ Keseimbangan berkurang } & $\begin{array}{l}\text { - Disediakan pegangan pada dinding sepanjang } \\
\text { jalur sirkulasi dan area basah. }\end{array}$ & Keselamatan \\
\hline & & $\begin{array}{l}\text { - Material lantai tidak licin namun masih } \\
\text { tergolong halus. }\end{array}$ & Keselamatan \\
\hline & & - Sudut pada perabotan tumpul. & Keselamatan \\
\hline & & - Wastafel dipisahkan dengan area basah. & Keselamatan \\
\hline & \multirow[t]{2}{*}{$\begin{array}{l}\text { Kemampuan mata } \\
\text { menyesuaikan terhadap } \\
\text { cahaya berkurang }\end{array}$} & $\begin{array}{l}\text { - Memiliki intensitas cahaya yang merata pada } \\
\text { ruang. }\end{array}$ & Kenyamanan \\
\hline & & $\begin{array}{l}\text { - Pencahayaan dua kali lipat dibanding } \\
\text { pencahayaan bagi manusia muda. }\end{array}$ & Kenyamanan \\
\hline & $\begin{array}{l}\text { Penyempitan pada jarak } \\
\text { pandang }\end{array}$ & - Memiliki bentuk dasar ruang yang teratur. & Kenyamanan \\
\hline & \multirow[t]{2}{*}{$\begin{array}{l}\text { Persepsi warna berubah } \\
\text { sehingga ketajaman terhadap } \\
\text { suatu objek berkurang }\end{array}$} & $\begin{array}{l}\text { - Penggunaan warna yang berbeda atau kontras } \\
\text { pada figur-figur yang penting agar mudah } \\
\text { ditangkap oleh mata lansia. }\end{array}$ & Kenyamanan \\
\hline & & $\begin{array}{l}\text { - Penggunaan warna berbeda sebagai penanda } \\
\text { area rawan. }\end{array}$ & Keselamatan \\
\hline & Pendengaran berkurang & $\begin{array}{l}\text { Pola perabotan komunikatif dan saling } \\
\text { berdekatan. }\end{array}$ & Kenyamanan \\
\hline & $\begin{array}{l}\text { Menggunakan rabaan untuk } \\
\text { membantu mempersepsikan } \\
\text { lingkungannya }\end{array}$ & $\begin{array}{l}\text { - Penggunaan tekstur berbeda sebagai penanda } \\
\text { area rawan. }\end{array}$ & Keselamatan \\
\hline & \multirow[t]{2}{*}{ Daya ingat menurun } & $\begin{array}{l}\text { - Penggunaan warna untuk memudahkan } \\
\text { mengingat. }\end{array}$ & Kenyamanan \\
\hline & & - Sirkulasi tidak berliku dan beraturan. & Kenyamanan \\
\hline & $\begin{array}{l}\text { Walaupun kurang peka } \\
\text { terhadap perbedaan suhu, } \\
\text { bau, dan rasa tetapi tetap } \\
\text { membutuhkan udara yang } \\
\text { sehat dan suhu yang nyaman } \\
\text { untuk beraktivitas. }\end{array}$ & $\begin{array}{l}\text { - Bukaan jendela minimal } 20 \% \text { dan ventilasi } \\
\text { minimal } 5 \% \text { sesuai dengan standar kenyamanan } \\
\text { termal pada SNI. }\end{array}$ & Kenyamanan \\
\hline Psikologis & $\begin{array}{l}\text { Peningkatan sensivitas } \\
\text { emosional }\end{array}$ & $\begin{array}{l}\text { - Penggunaan warna hangat dan ringan pada } \\
\text { ruang. }\end{array}$ & Kenyamanan \\
\hline
\end{tabular}




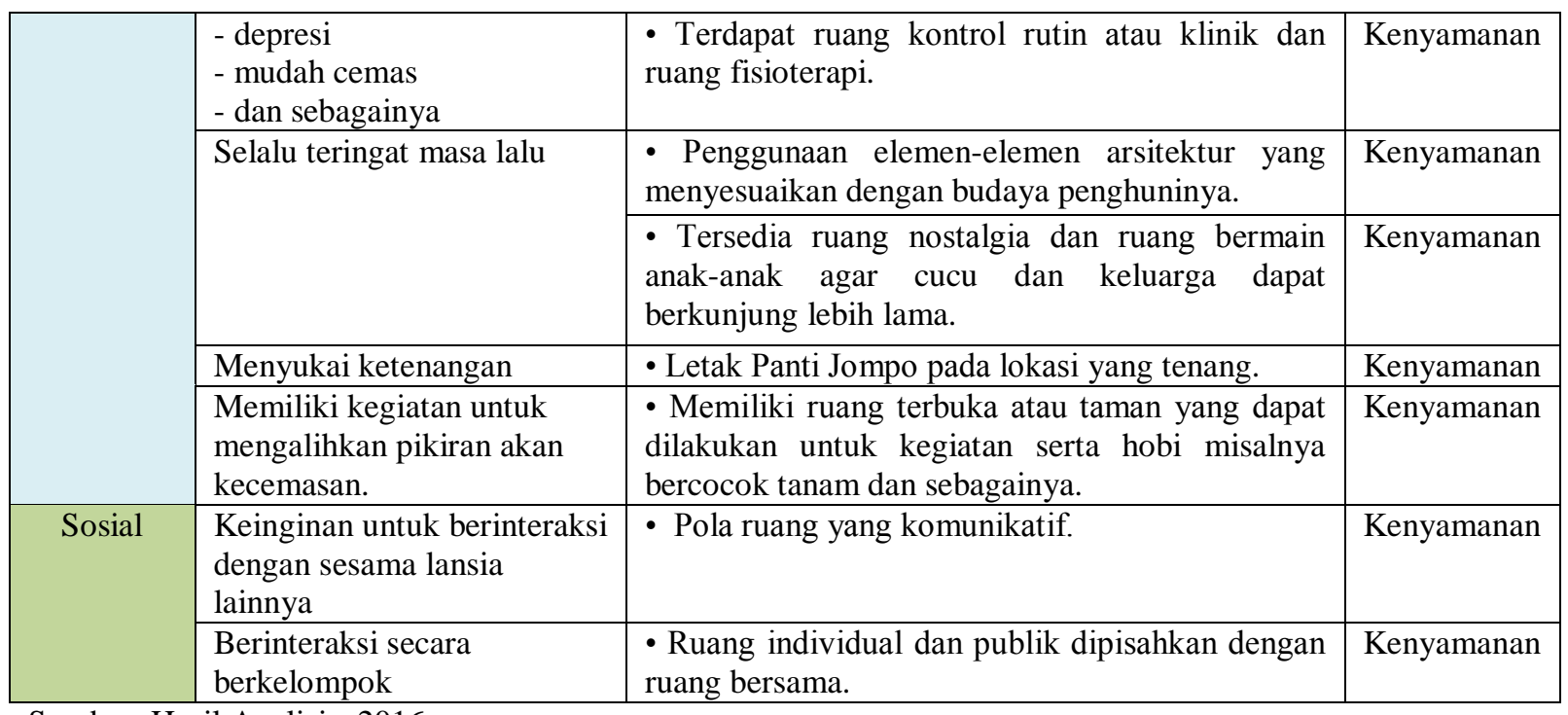

Sumber: Hasil Analisis, 2016

\section{Hasil dan Pembahasan}

\section{Kriteria ditinjau dari aspek keselamatan:}

a. Pergerakan

Penurunan fisik pada lansia menyebabkan lansia rentan akan masalah kecelakaan kecil yang mungkin terjadi saat beraktivitas dan dapat berakibat fatal bagi lansia. Untuk menunjang keselamatan lansia maka ditinjau dari pergerakan lansia sebagai berikut:

i. Sirkulasi

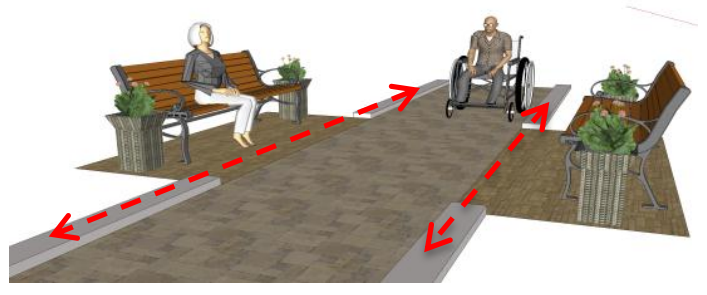

Gambar 4. Sirkulasi yang bebas hambatan Sumber: Hasil Analisis, 2016
Sirkulasi bebas hambatan misalnya dengan tidak adanya elemen struktural atau kolom yang menonjol pada jalur sirkulasi dan kursi untuk duduk sebaiknya mundur agar sirkulasi bersih. Selain itu, sudut luar pada sirkulasi sebaiknya tidak tajam atau siku, selain untuk memudahkan lansia yang menggunakan kursi roda untuk berputar saat beraktivitas, juga menghindari terbentur ketika lansia melewatinya.
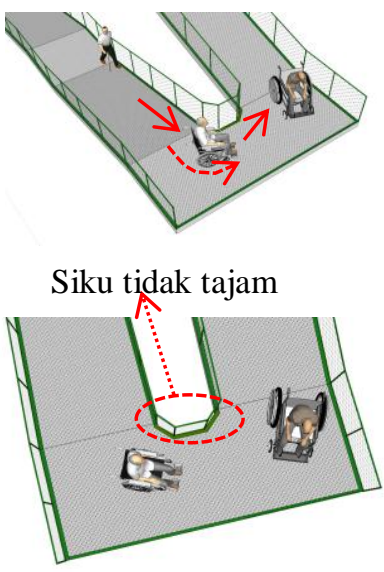

Gambar 5. Sudut luar tidak siku atau melengkung

Sumber: Hasil Analisis, 2016 
Sudut pada perabotan yang digunakan juga sebaiknya melengkung agar lansia tidak mudah terbentur ketika beraktivitas.

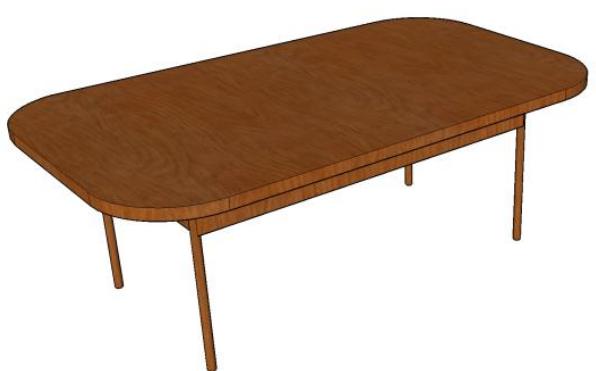

Gambar 6. Sudut luar tidak tajam atau melengkung

Sumber: Hasil Analisis, 2016
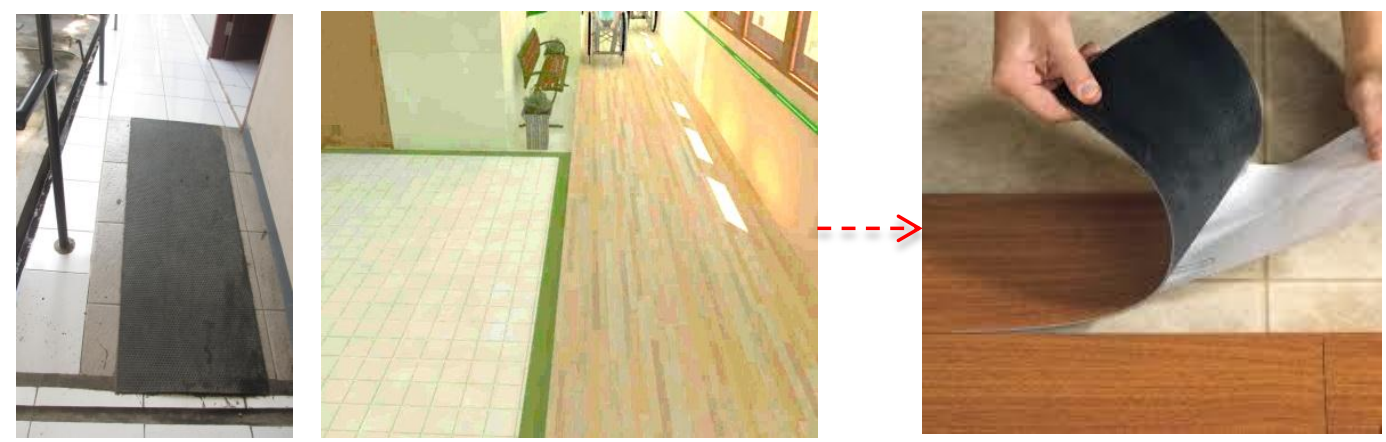

Gambar 7. Sudut luar tidak tajam atau melengkung Sumber: Google image.com, 2016

iii. Pelengkap keselamatan

Hal yang paling diperlukan untuk melengkapi pergerakan lansia adalah tersedianya handrail pada jalur sirkulasi dan area basah seperti kamar mandi. Selain itu sirkulasi relatif datar, apabila memungkinkan terdapat perbedaan lantai maka digunakan ramp dengan kelandaian 5-7 ${ }^{\circ}$ dengan tersedianya tempat perhentian setiap $6 \mathrm{~m}$. Pertimbangan ini dikarenakan pergerakan lansia yang perlu pegangan untuk menopang tubuhnya agar tidak mudah terpeleset dan gerak lansia ii. Material

Lansia mengalami penurunan keseimbangan sehingga mudah jatuh saat berjalan. Material lantai yang digunakan agar aman untuk lansia adalah material dengan tekstur kasar namun masih halus sehingga tidak licin, misalnya penggunaan material vinyl untuk lantai. Untuk ramp digunakan material lantai yang agak merekat seperti karet agar tidak licin pada saat berjalan di ramp. 


\section{b. Penglihatan lansia}

i. Warna

Warna selain memberikan efek psikologis, juga dapat memberikan informasi terhadap lingkungan sekitarnya. Karena mata lansia mengalami perubahan dan lebih sensitif terhadap warna, cahaya, dan jarak, maka warna-warna yang kontras dapat membantu lansia memudahkan mendapat informasi terhadap lingkungannya. Misalnya pemberian warna mencolok pada handrail yang sangat berbeda dengan warna dindingnya atau pada sisi sirkulasi diberi garis warna mencolok agar terlihat jelas jarak dan batas sirkulasinya.
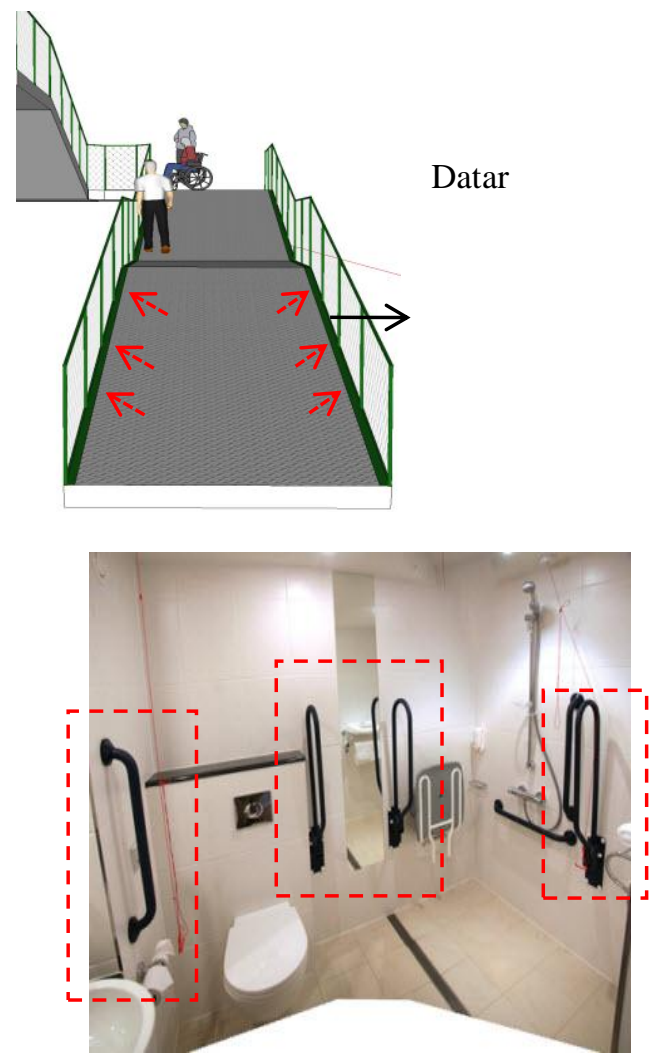

Gambar 9. Warna kontras untuk membantu lansia mempersepsikan lingkungannya

Sumber: Google image.com, 2016

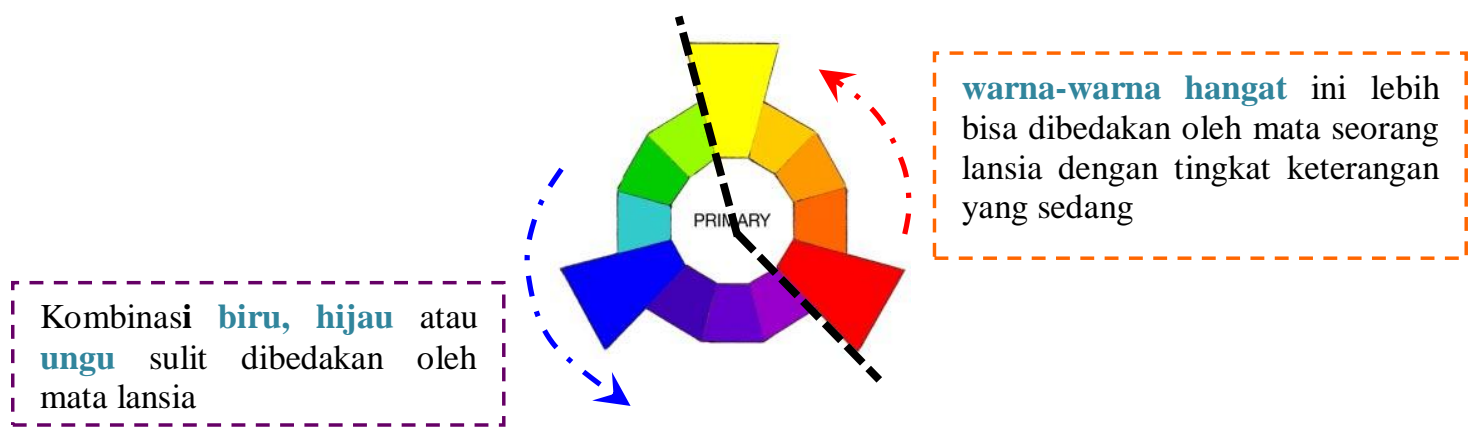

Gambar 10. Penurunan persepsi warna pada lansia

Sumber: Google image.com, 2016

c. Taxtile

Ketika menyentuh suatu objek, tidak hanya persepsi sentuhan yang dirasakan, tetapi dari sentuhan tersebut dapat mempersepsikan kasar, halus, bentuk dan proporsi suatu benda (haptic).
Dengan material yang berbeda pada ujung handrail atau area rawan dapat membantu lansia mempersepsikan lingkungannya. 
2. Kriteria ditinjau dari aspek kenyamanan:

a. Pergerakan

Penurunan fisik pada lansia tidak hanya mempengaruhi keselamatan, tetapi juga mempengaruhi kenyamanan lansia saat bergerak. Hal tersebut ditinjau sebagai berikut:

1. Jarak antar ruang

Jarak antar ruang yang sering digunakan sehari-hari sebaiknya saling berdekatan dan tidak lebih dari 40 meter. Jika memungkinkan adanya ruang dengan jarak yang lumayan jauh disarankan adanya tempat untuk beristirahat dalam perjalanan sepanjang koridor atau jalur sirkulasi.

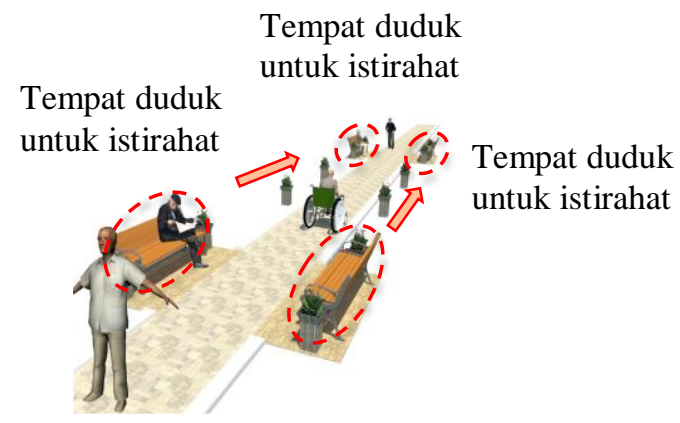

Gambar 11. Jarak untuk gerak nyaman lansia

Sumber: Hasil Analisis, 2016

\section{Sirkulasi}

Sirkulasi sangat penting dalam merancang Panti Jompo. Sirkulasi yang baik untuk lansia adalah sirkulasi yang bebas hambatan terutama untuk lansia yang telah menggunakan alat bantu berjalan seperti kursi roda dan tongkat. Dimensi alat bantu berjalan lansia yang paling besar adalah kursi roda dengan lebar $63 \mathrm{~cm}$, panjang 107,5 $\mathrm{cm}$ dan tinggi $96,5 \mathrm{~cm}$ menjadi patokan dalam merancang sirkulasi. Dan ukuran sebaiknya sesuai untuk sirkulasi koridor bagi lansia adalah dapat dilalui oleh dua buah kursi roda secara bersamaan.
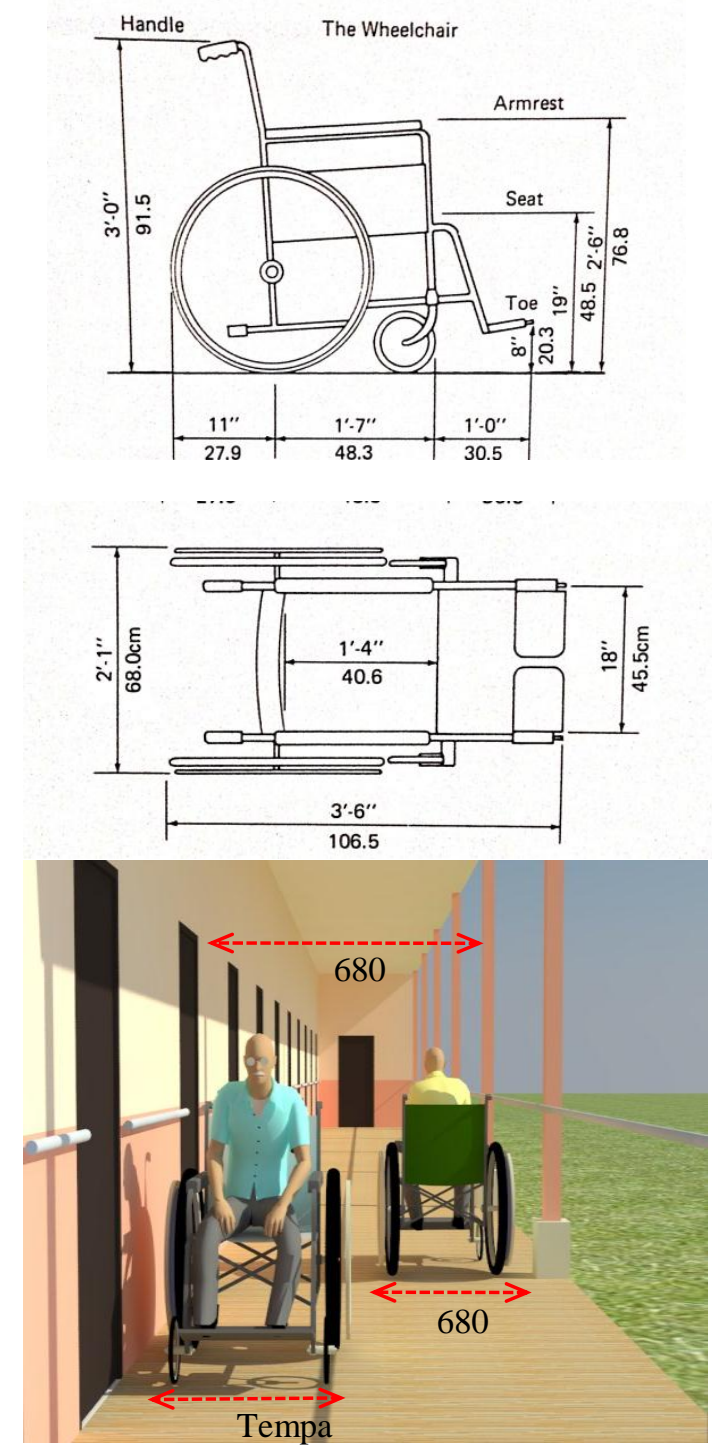

Gambar 12. Dimensi kursi roda (kiri dan tengah) dan lebar minimum sirkulasi (kanan) Sumber: Hasil Analisis, 2016

3. Kepadatan penghuni ruang Luas ruang yang nyaman untuk disable atau lansia yang 
menggunakan kursi roda adalah $7 \mathrm{~m}^{2}$ orang atau $12 \mathrm{~m}^{2}$ untuk dua orang (Neufret). Dengan sirkulasi minimal 1,52 m (gerak kursi roda hingga dapat berputar) akan memberikan kenyamanan gerak bagi lansia beraktivitas. Hal ini agar lansia yang menggunakan kursi roda dapat bergerak dengan leluasa dan nyaman di dalam ruangan.

b. Kelompok sosial

1. Pola penataan ruang

Penataan ruang dapat mempengaruhi perilaku dan kenyamanan lansia dalam beraktivitas. Karena lansia senang untuk berinteraksi dengan sesama teman sebayanya, maka pola ruang yang komunikatif dapat memberikan perilaku untuk dapat saling berinteraksi dengan penghuni lainnya. Ada beberapa pola komunikatif di antaranya adalah pola ruang yang memusat dan pola ruang yang radial.

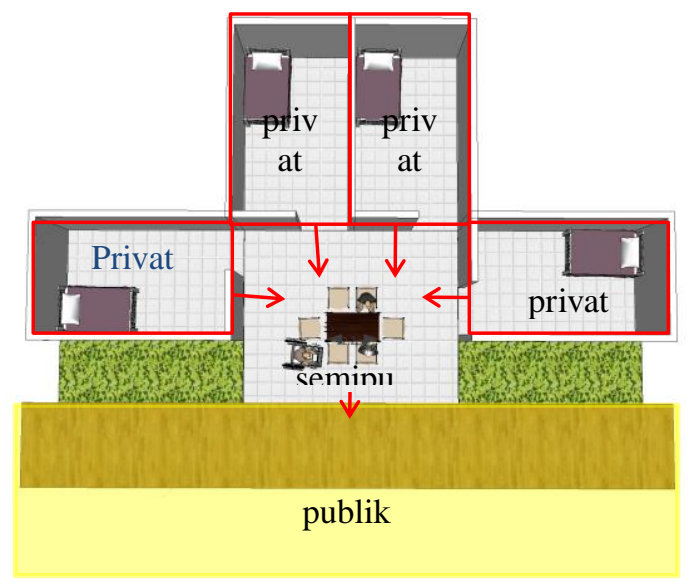

Gambar 13. Pola ruang yang radial

Sumber: Hasil Analisis, 2016

2. Privasi (ruang personal dan teritorial)
Pada teori psikologi arsitektur bahwa seseorang memiliki privasi yang mempengaruhi tingkat kenyamanan seseorang. Tidak terkecuali untuk lansia, lansia juga memerlukan privasi. Dengan pengaturan posisi perabotan dapat memberikan area teritorial dan personal bagi masing-masing penghuninya. Misalnya diletakkan meja di tengah-tengah antara tempat tidur yang satu dengan yang lain untuk membatasi area personal sehingga lansia lebih nyaman.

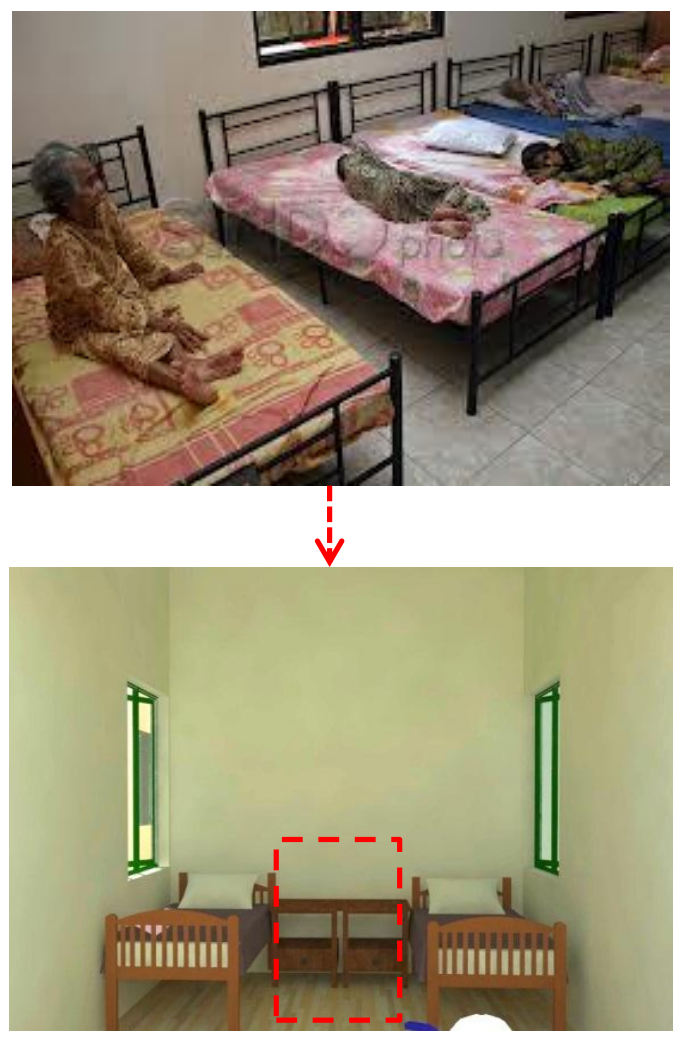

Gambar 14. Ilustrasi kondisi kamar tidur Sumber: Hasil Analisis, 2016

Lansia cenderung bersosialisasi secara berkelompok sehingga dibutuhkan ruang bersama pada tiap beberapa unit kamar. Dan untuk mencegah area publik berbatasan 
langsung dengan kamar tidur maka dipisahkan dengan ruang bersama. Ruang bersama dapat menjadi tempat berkumpul dengan lansia lainnya dalam area tersebut. Ketika ingin lebih bersosialisasi dengan penghuni lainnya, dapat ke area publik yaitu taman yang dapat diletakkan di tengah-tengah area bangunan.
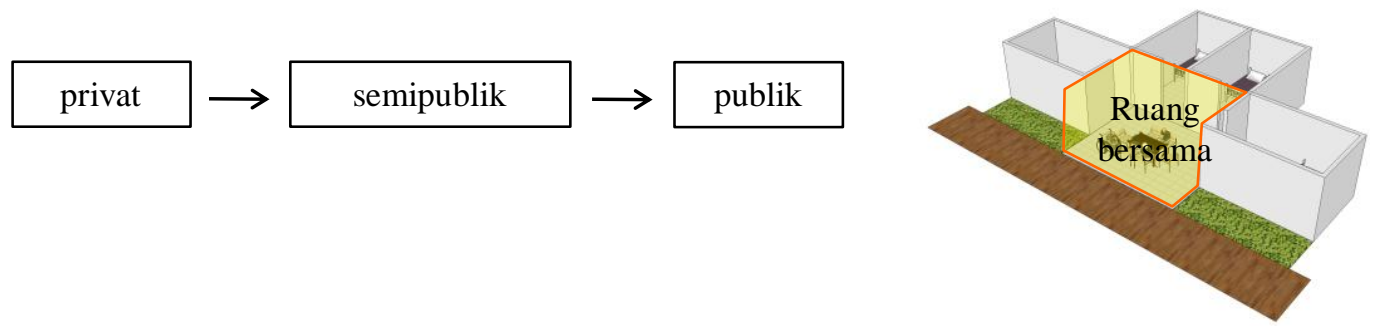

Gambar 15. Ruang bersama yang menghubungkan area individual dengan area publik Sumber: Hasil Analisis, 2016

c. Penglihatan lansia

1. Warna

Warna dapat memberikan efek psikologis bagi penghuni ruangnya. Dari hasil kuisoner yang dilakukan pada penelitian ini, lansia cenderung memilih warna-warna yang ringan. Warna yang terlalu terang dapat memberikan efek yang tidak nyaman bagi mata lansia. Dan berdasarkan studi literatur bahwa warna-warna hangat dapat memberikan efek psikologis yang nyaman dan tenang sehingga warnawarna yang cocok untuk lansia adalah warna-warna ringan dan hangat. Selain itu warna-warna ringan dapat memberikan efek luas dan kelegaan pada ruang.

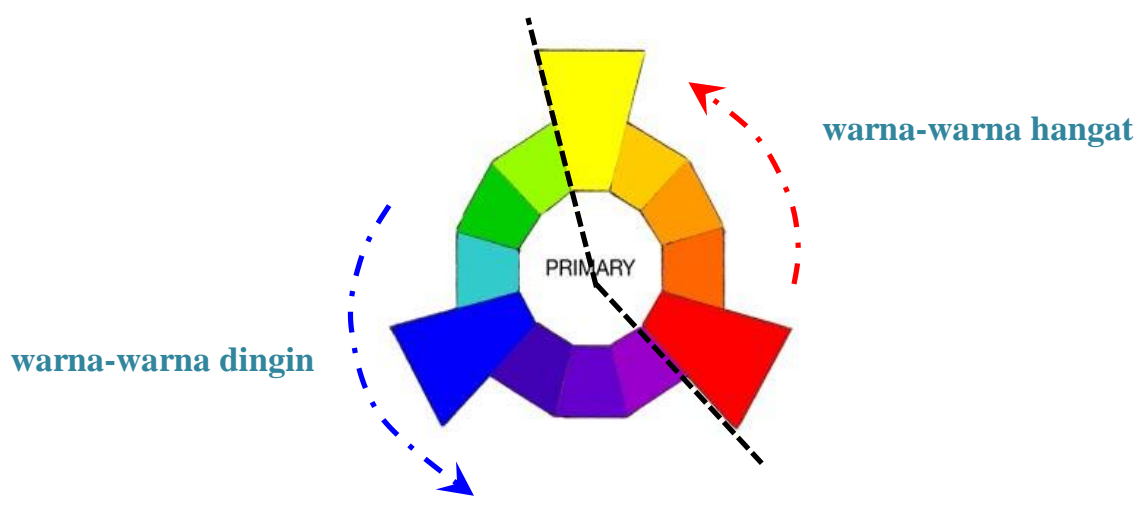

Gambar 16. Warna dingin dan warna hangat

Sumber: Hasil Analisis, 2016 


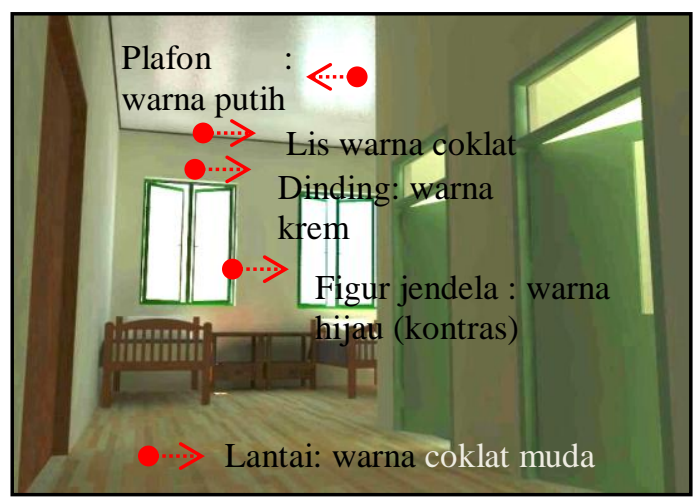

Gambar 17. Ruang dengan warna ringan dan hangat

Sumber: Hasil Analisis, 2016

2. Pencahayaan

i. Pencahayaan alami

Pencahayaan untuk lansia sebaiknya merata (pencahayaan tidak terlalu terang juga tidak terlalu gelap) untuk menghindari kesilauan karena mata lansia telah mengalami pengurangan dalam menyaring cahaya yang masuk ke retina. Bukaan jendela dapat dengan kisikisi kayu ataupun jendela biasa asalkan cahaya yang masuk ke ruangan merata.
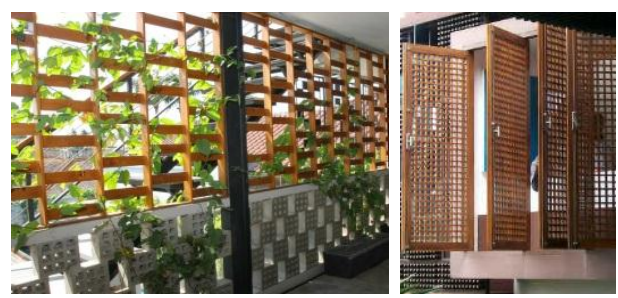

Gambar 18. Alternatif kisi-kisi sebagai bukaan pada koridor

Sumber: Google image.com, 2016

Pencahayaan alami sebaiknya dimaksimalkan untuk menghemat energi. Pencahayaan dari bukaan sebaiknya lebih dari satu sisi sehingga cahaya yang masuk kek ruangan lebih merata. Pencahayaan alami juga sebaiknya pencahayaan yang tidak langsung sehingga cahaya yang masuk ke ruangan lembut dan tidak menyebabkan glare atau silau untuk mata lansia yang telah mengalami penurunan dalam mentranspantasi cahaya yang masuk ke mata.

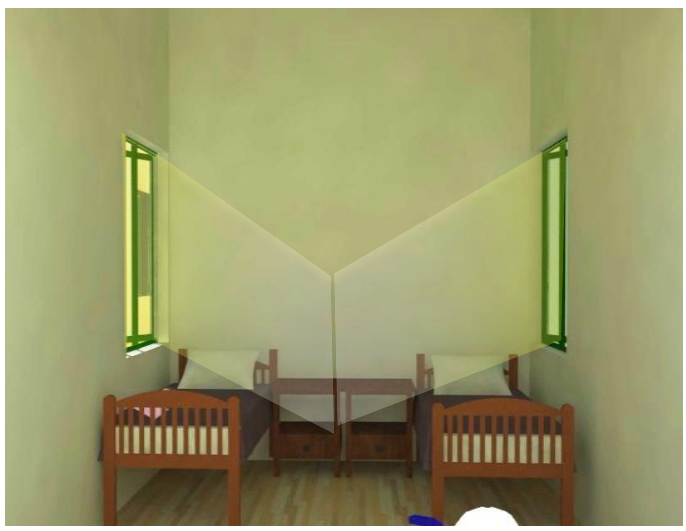

Gambar 19. Bukaan jendela yang menyilang pada kamar tidur

Sumber: Hasil Analisis, 2016

ii. Pencahayaan buatan

Pencahayaan untuk lansia saat beraktivitas sebaiknya $50 \%$ lebih besar dibandingkan untuk manusia yang masih muda yaitu sekitar 300 lux. Dan menurut observasi, pencahayaan di kamar tidur tidak melebihi 50 lux karena lansia cenderung untuk tidur ketika masuk ke kamar dan lansia tidur cenderung menggunakan lampu, selain itu lebih aman daripada mematikan lampu karena resiko tersenggol perabotan lebih besar.

d. Kondisi udara (termal)

i. Suhu udara, kelembaban dan kecepatan angin

Walaupun lansia kurang peka terhadap perbedaan suhu, rasa, dan bau, namun lansia tidak tahan 
dengan suhu yang terlalu panas atau terlalu dingin. Di negara tropis suhu memang cenderung hangat. Beberapa penelitian mengungkapkan bahwa beberapa kondisi udara dengan temperatur, kelembaban udara, dan kecepatan udara berbeda dapat memberikan kenyamanan termal yang dirasakan sama. Oleh sebab itu, sebaiknya memaksimalkan penghawaan alami di daerah tropis sangat baik karena dapat mempengaruhi aliran udara yang masuk ke ruangan. Dengan bukaan, landscape dan orientasi bangunan yang menunjang, dapat membantu menurunkan suhu di dalam ruangan tersebut.

Penghawaan yang baik adalah penghawaan alami dimana udara di dalam suatu ruang terus berganti dengan udara luar. Dalam arsitektural, penghawaan yang baik adalah memiliki bukaan jendela minimal $20 \%$ ruang dan ventilasi minimal $5 \%$ dari luas ruangan (SNI). Bukaan yang menyilang juga dapat memaksimalkan pola aliran udara dalam suatu ruangan dan menurunkan suhu ruangan.
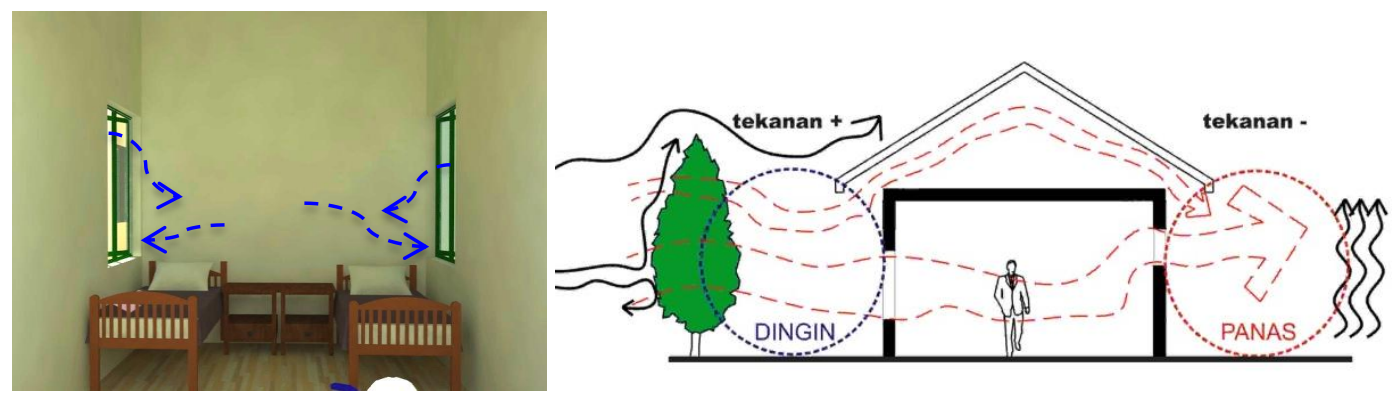

Gambar 20. Bukaan jendela yang menyilang (kiri) dan pola aliran udara (kanan) Sumber: Hasil Analisis, 2016

ii. Penciuman (bau)

Bau dapat memberikan "rasa" dalam arsitektur. Untuk memberikan kesan asri dapat dengan memberikan aroma tanaman. Misalnya aroma tanaman lemon terbukti selain harum juga dapat berfungsi sebagai antibakteri di dalam ruangan. Aroma lavender dapat membantu menurunkan insomnia dan mual. Dari hasil penelitian sebuah universitas di Australia juga menemukan aroma potongan rumput dapat meredakan stres karena potongan rumput melepaskan zat kimia yang mampu mencegah penurunan mental di usia tua serta memberikan rasa gembira dan rileks. Aroma rumput dapat bekerja langsung pada otak khususnya yang berkaitan dengan emosi dan memori dimana area tersebut yang mengontrol pelepasan hormon stres. 


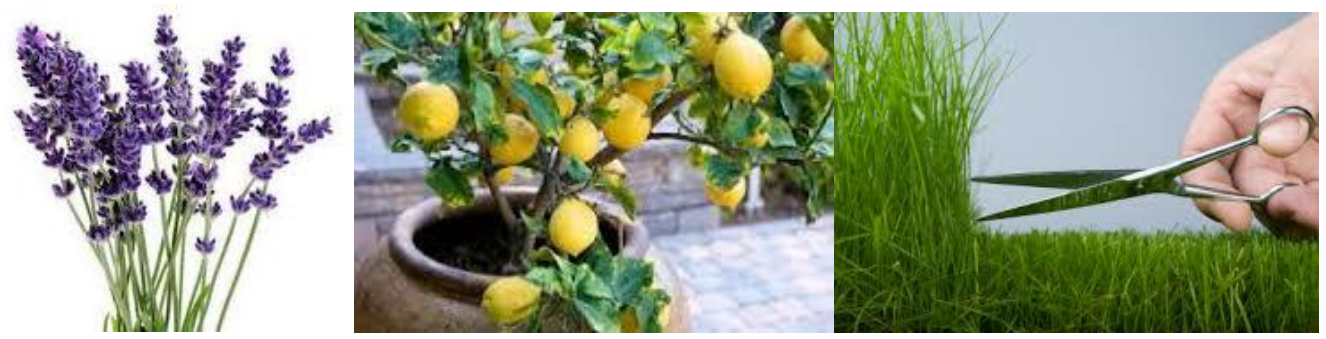

Gambar 21. Tanaman beraroma

Sumber: Google image.com, 2016

e. Pendengaran pada lansia

i. Pola layout perabot

Penurunan pendengaran pada lansia mempengaruhi jarak yang digunakan untuk berkomunikasi. Penyusunan jarak dan orientasi kursi dapat membantu lansia berinteraksi dengan penghuni lainnya. Posisi perabotan sebaiknya memusat atau radial dengan jarak yang cukup dekat atau antara 0,45-1,2 $\mathrm{m}$ agar lansia yang mengalami penurunan pendengaran dapat saling berinteraksi dengan nyaman.

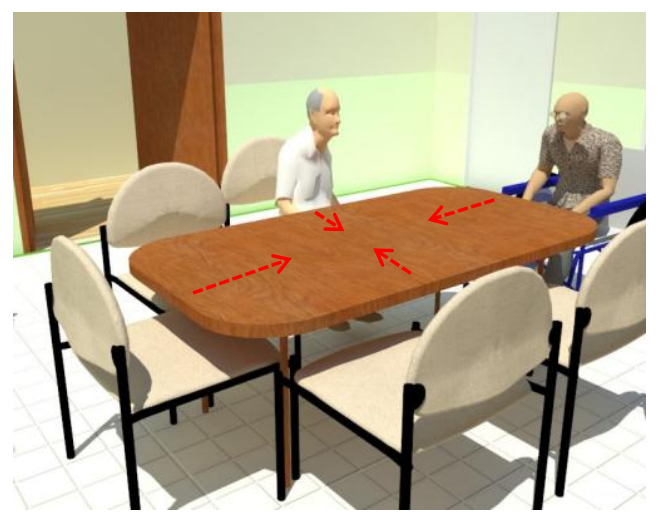

Gambar 22. Bentuk dan pola layout perabotan yang komunikatif

Sumber: Hasil Analisis, 2016

Selain itu, suara atau bunyi dapat memberikan efek positif. Lansia cenderung menyukai ketenangan dan lingkungan yang asri sebagai penunjang. Dengan suara-suara air mengalir dan suara kicauan burung dapat memberikan suasana asri secara psikologis bagi yang mendengarkannya journal.uajy.ac.id).

f. Penunjang psikologis bagi $\underline{\text { lansia }}$

i. Memori dan persepsi dalam menghadapi kematian

Di Panti Jompo, terlihat foto-foto masa dulu dan foto keluarga yang digantung di area tempat tidur selain sebagai aktualisasi diri, juga merupakan kenangan yang membuat lansia nyaman. Untuk menunjang hal tersebut maka perlu disediakan ruang nostalgia bagi lansia agar lansia dapat saling bercerita dengan teman sebayanya.

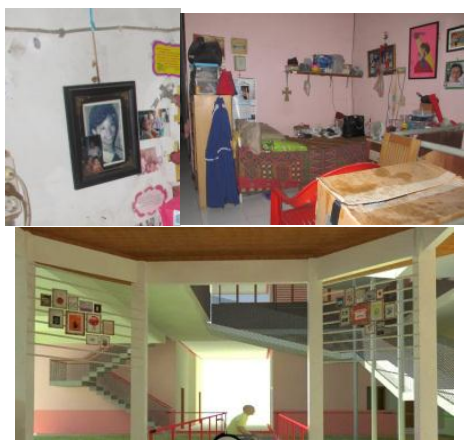

Gambar 23. Existing perabotan lansia di panti jompo (atas) dan ilustrasi wadah untuk menaruh foto pribadi pada gazebo dapat sekaligus menjadi ruang nostalgia (bawah)

Sumber: Hasil Analisis, 2016 


\section{Kesimpulan}

Berdasarkan analisis yang telah dilakukan, maka ditarik kesimpulan bahwa dalam perancangan arstitektur, kenyamanan fisik memiliki korelasi dengan kenyamanan psikologis penghuninya. Arsitektur dapat menunjang rasa nyaman bagi penghuninya. Apabila secara fisik terpenuhi, maka sedikit banyak memberikan dampak yang positif juga bagi psikologis penghuninya. Kenyamanan dan keselamatan bagi lansia adalah suatu keadaan didapatkannya kemudahan dalam beraktivitas secara mandiri serta terhindar dari resiko kecelakaam kecil yang mungkin terjadi.

Aspek kenyamanan dan keselamatan tersebut ditinjau dari pergerakan lansia yaitu jarak antar ruang yang sering digunakan lansia sehari-hari saling berdekatan, sirkulasi minimal $1,52 \mathrm{~m}$ yaitu dapat dilalui dua buah kursi roda secara bersamaan dan bebas hambatan, lantai relatif datar dan menggunakan ramp apabila terdapat perbedaan ketinggian lantai, terdapat handrail pada jalur sirkulasi agar lansia memiliki pegangan dan tidak mudah terpeleset ketika berjalan, dan detail sudut luar sebaiknya tidak siku yaitu melengkung. Selain itu, dikaji dari segi visual lansia yaitu penggunaan warna yang ringan dan hangat pada ruang, penggunaan warna kontras dan tekstur berbeda sebagai pemberi informasi serta penanda area rawan, bukaan jendela yang merata pada ruang (tidak ada perbedaan pencahayaan yang signifikan pada ruang. Bila dikaji dari kecenderungan sosial lansia, yaitu lansia senang untuk berinteraksi dengan sesama lansia lainnya sehingga bentuk dasar pola ruang komunikatif (memusat atau radial) dan terbuka. Dan karena lansia cenderung berinteraksi secara berkelompok maka menggunakan pola klaster, untuk memisahkan area individual dengan area publik dengan masing-masing klaster memiliki ruang bersama yang dapat digunakan lansia untuk makan dan bersantai.

Sebagai penunjang kebutuhan psikologis lansia, sebaiknya ditambahkan ruang nostalgia dan fasilitas lain yang menarik keluarga untuk lebih sering berkunjung ke Panti Jompo karena bagaimanapun keluarga sangat berperan penting dalam memberikan psikologis yang positif bagi lansia.

\section{Daftar Pustaka}

Baucom, Alferd H. \& Robert J. Grosch. (1996). Hospitality Design For Graying Generation. John Wiley \& Sons, Inc, Canada.

Buletin Jendela Data dan Informasi Kementerian Kesehatan RI. (2013).

Halim, Deddy. (1999). Psikologi Arsitektur: Pengantar Kajian Lintas Disiplin. Grasindo, Jakarta.

http://e-

journal.uajy.ac.id//1070/3/2TA1252 0.pdf (diakses 22 Januari 2016).

Kartinah \& Sudaryanto, Agus. (2008). Masalah Psikososial pada Lansia, (Online). Berita Ilmu Keperawatan, ISSN 1979-2697,

http://publikasiilmiah.ums.ac.id/bitst ream/handle/123456789/486/2h.pdf ?sequence $=1$.

Keputusan Menteri Sosial RI No. 4/PRS-3/KPTS/2007 tentang Pedoman Pelayanan Sosial Lanjut Usia Dalam Panti. 
McCullough, Chyinthia. (2010). Evidence-Based Design for Healthcare Facilities. Edward Brothers, Inc, USA.

Sabrina, Evelin. (2008). Rumah Tinggal sebagai Therapeutic. http://lib.ui.ac.id/file?file=digital/12 5113-050805.pdf. Diakses 28 Mei 2015. 
JURNAL ARTEKS VOL. I, No. 1 - DESEMBER 2016/ISSN 2541-0598 